\title{
Pembuatan dan Pelatihan Mengoperasikan Display LED Dot Matrix berbasis NodeMCU ESP8266 sebagai Alarm Pengingat Sholat di Mushola Nurul Huda Poncokusumo-Malang
}

\author{
Zakki Fuadi Emzain ${ }^{1 *}$ Utsman Syah Amrullah2, Nanang Qosim³, Ahmad Hanif \\ Firdaus $^{4}$, Am. Mufarrih ${ }^{5}$ \\ 1,23,3,4,5eknik Mesin, Politeknik Negeri Malang, Indonesia, 65141
}

E-mail: zfemzain@polinema.ac.id

DOI: https://doi.org/10.37339/jurpikat.v1i2.334

\author{
Info Artikel: \\ Diterima : \\ 2020-10-17 \\ Diperbaiki : \\ 2020-10-26 \\ Disetujui : \\ 2020-10-26
}

Kata Kunci: Display LED, NodeMCU ESP8266, Jam Digital, Waktu Sholat, Alarm Azan Iqomah

\begin{abstract}
Abstrak: Pemanfaatan teknologi seperti display LED dot matrix yang berbasis NodeMCU ESP8266 semakin luas penggunaannya. Tidak hanya digunakan untuk iklan dan promosi di toko-toko bisnis saja tapi juga bisa dimanfaatkan di Masjid atau mushola untuk menunjang ibadah. Mushola Nurul Huda merupakan salah satu mushola di Kecamatan Poncokusumo Kabupaten Malang tepatnya di komplek Pondok Pesantren Nurul Huda yang masih menggunakan kalender/pamflet jadwal sholat secara manual dalam melihat jadwal sholat lima waktu sehingga akan membuat takmir selalu melihat jadwal tiap harinya. Oleh karena itu perlu teknologi display LED dot matrix dan diaplikasikan di mushola tersebut serta pelatihan kepada takmir mushola terkait cara mengoperasikannya. Metode yang digunakan adalah metode Participatory Rural Appraisal (PRA). Tahapan pelaksanaan kegiatan ini adalah pembuatan, pelatihan mengoperasikan, dan pemasangan running text. Hasil evaluasi menunjukkan bahwa running text dapat berfungsi dengan baik dengan semua lampu LED menyala dan program berfungsi sesuai keinginan serta takmir mushola mampu mengoperasikan dan mensetting running text dengan baik.
\end{abstract}


Keywords: LED Display, Nodemcu Esp8266, Digital Clock, Prayer Time, Iqomah Azan Alarm
Abstract: The use of technology such as dot matrix LED displays based on the NodeMCU ESP8266 is increasingly being used. Not only used for advertising and promotion in business shops, but also can be used in mosques or prayer rooms to support worship. Nurul Huda Mushola is one of the prayer rooms in Poncokusumo Subdistrict, Malang Regency, to be precise in the Nurul Huda Islamic Boarding School complex, which still uses a calendar / pamphlet prayer schedule manually in viewing the five daily prayer schedules so it will make takmir always see the schedule every day. Therefore, a dot matrix LED display technology is needed and it is applied in the prayer room as well as training for mushola takmirs regarding how to operate it. The method used is the Participatory Rural Appraisal (PRA) method. The stages of implementing this activity are the creation, training to operate, and installation of running text. The evaluation results show that the running text can function properly with all the LED lights on and the program functions as desired and the prayer room takmir is able to operate and set up running text properly.

\section{Pendahuluan}

Dalam dekade terakhir ini, perkembangan teknologi sangatlah pesat. Hampir di setiap kehidupan sehari-hari tidak lepas dari pemanfaatan teknologi. Kemajuan tersebut sangat berdampak signifikan pada semua bidang baik dalam dunia pendidikan, ekonomi, dan sosial. Contoh teknologi yang dihasilkan dan sangat berguna diantaranya adalah teks berjalan (running text) dan jam digital (Wijaya dan Alfadian 2015). Running text LED (Light Emitting Diode) terutama display dot matrix dapat menampilkan karakter, teks dan grafis dengan sinkronisasi komputer menggunakan control mikro, grafis, dan gambar untuk memainkan semua jenis informasi secara real-time, sinkron, dan jelas (Waluyo dan Adisutjipto 2018). LED ini memiliki memiliki kelebihan diantaranya tingkat kecerahan tinggi, tegangan kerja rendah, konsumsi daya kecil, miniaturisasi, umur panjang, tahan gangguan dan kinerja yang stabil (Zainuri, Wibawa, dan Maulana 2016).

Alat running text LED dapat dimanfaatkan sebagai media penyampaian informasi elektronik atau bisa juga sebagai media iklan atau promosi di depan toko atau tempat bisnis. Salah satu dari pemanfaatan running text LED adalah dapat diaplikasikan di masjid/mushola sebagai jam digital, informasi waktu sholat, alarm pengingat azan dan iqomah, serta penyampaian pesan-pesan atau pengumunanpengumuman yang ingin disampaikan oleh takmir masjid kepada jamaah. Running 
text LED ini dapat menggantikan peran jadwal atau kalender waktu sholat dari kertas yang biasa di tempel pada papan pengumuman atau dekat mimbar tempat azan masjid/mushola. Dengan adanya jam digital ini dapat membantu muazin untuk melaksanakan azan dan juga iqomah tepat waktu tanpa menunggu dahulu azan dari masjid sekitar.

Nurul Huda merupakan salah satu mushola yang ada di Kabupaten Malang tepatnya berlokasi di Pondok Pesantren Nurul Huda, Desa Pajaran, Kecamatan Poncokusumo, Kabupaten Malang. Fakta dilapangan takmir Mushola Nurul Huda untuk mengetahui jadwal sholat lima waktu subuh, zuhur, asar, magrib dan isya masih secara manual menggunakan kalender/pamflet/selebaran jadwal sholat, termasuk juga jadwal waktu imsak pada saat bulan puasa ramadan. Selain masalah jadwal waktu sholat, jamaah mushola Nurul Huda juga terbiasa menunda melakukan sholat sunah antara azan dan iqomahnya sehingga secara langsung menyebabkan tertundanya sholat wajib berjamaah.

Guna mengatasi hal ini diperlukan sebuah peralatan running text LED display sebagai jam digital jadwal sholat yang dapat diprogram, memiliki fitur alarm dan mampu menunjukkan jadwal waktu sholat secara tepat (Zondra dan Yuvendius 2018). Manfaat yang didapat adalah pertama dengan adanya aplikasi tepat guna ini jamaah mushola Nurul Huda dan santri Ponpes Nurul Huda dapat mengetahui jadwal waktu sholat setiap harinya dengan tepat. Kedua dengan jam digital dan alarm yang dapat disetting waktunya maka akan meningkatkan ketertiban waktu dalam melantunkan zikir atau wirid harian sebelum iqomah.

Meskipun demikian, tidak cukup hanya pemberian alat running text LED kepada takmir Mushola Nurul Huda, tapi juga perlu diikuti dengan perkembangan pada Sumber Daya Manusia (SDM) atau takmir/pengurus Mushola Nurul Huda. Dalam hal ini manusia sebagai pengguna teknologi harus mampu memanfaatkan teknologi yang ada saat ini, maupun perkembangan teknologi tersebut (Nasrullah, Trisanto, \& Susanto 2019 dan Finawan \& Yusman 2020). Oleh karena itu, perlu juga dilakukan pelatihan dalam mengoperasikan running text LCD kepada takmir Mushola Nurul Huda. Pihak takmir dapat menyetting waktu yang diinginkan seperti waktu sholat asar yang agak ditunda atau waktu sholat isya di hari-hari tertentu karena ada acara taklim, zikir, wirid, atau kegiatan insidental yang lain. Takmir bisa mengoperasikan untuk membuat pesan atau pengumuman yang ingin disampaikan secara mandiri. 


\section{Metode}

Metode yang digunakan dalam kegiatan pengabdian ini adalah metode Participatory Rural Appraisal (PRA) yaitu kegiatan yang melibatkan masyarakat sasaran dalam pelaksanaannya. Terdapat 4 (empat) tahapan kegiatan utama dalam pelaksanaan kegiatan ini seperti flowchart pada Gambar 1, dengan rincian sebagai berikut:

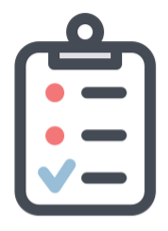

Sosialisasi

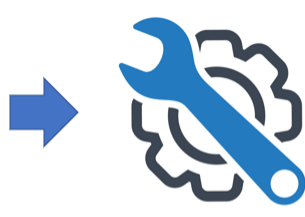

Pembuatan Running Text

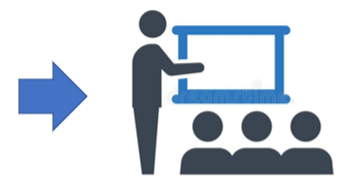

Pelatihan Mengoperasikan Running Text

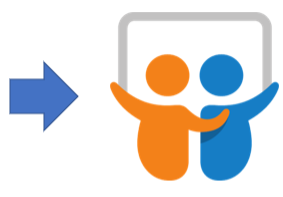

Pemasangan Running Text

Gambar 1. Flowchart Tahapan Kegiatan

\section{Sosialisasi}

Tahap pertama adalah sosialisasi langsung ke pihak takmir Mushola Nurul Huda Pondok Pesantren Nurul Huda Poncokusumo Malang. Pada tahap ini bertujuan untuk silaturahmi, berdiskusi menggali informasi terkait masalah dan kendala yang dihadapi dalam pelaksanaan waktu azan dan iqomah, informasi saldo kas masjid, serta membuat kesepakatan kerjasama. Pada tahapan ini juga dilakukan tinjau lokasi untuk mengukur space yang tersedia pada dinding depan atau samping masjid dan mensimulasikan instalasi pemasangan running text LED. Gambar 2 menunjukan foto Mushola Nurul Huda dan ruang sekretariatan takmir.
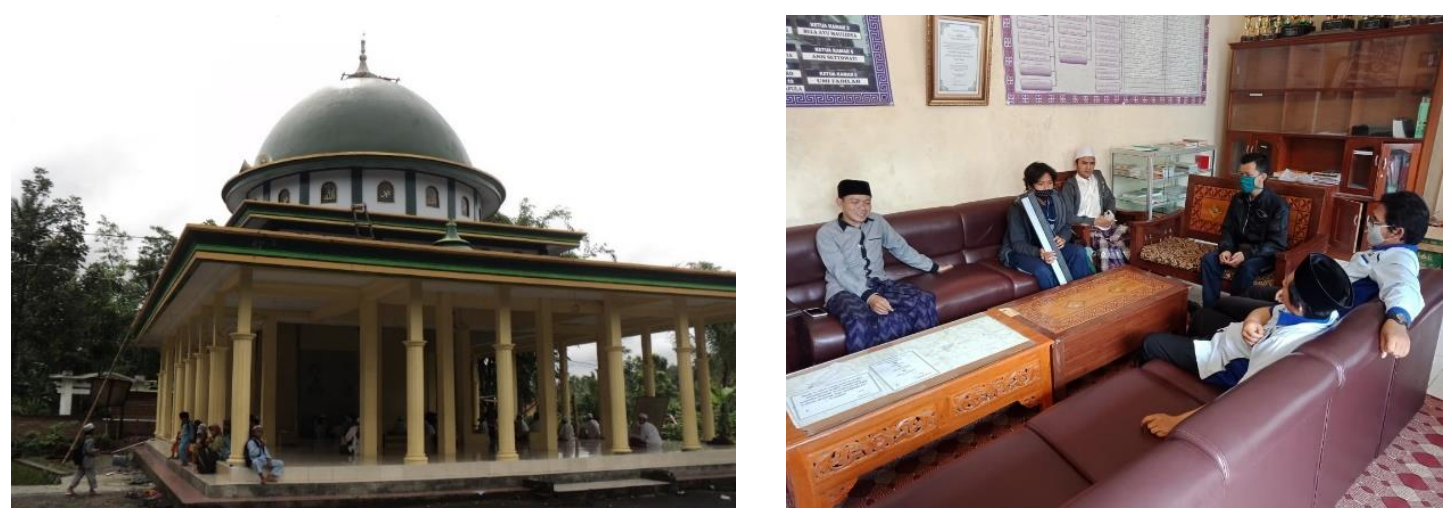

Gambar 2. Sosialisasi ke Mushola Nurul Huda dan Pihak Takmir 


\section{Pembuatan Running Text LED}

Tahap kedua adalah pembuatan running text LED dengan ukuran $100 \times 20 \mathrm{~cm}$. Dimensi ini didapat berdasarkan space yang tersedia di dinding mushola sebelumnya dan ukuran sedang yang ada di pasaran. Pembuatan running text LED ini dilakukan oleh mekanik dan programer dari mahasiswa dan dosen polinema selama kurang lebih seminggu. Gambar 3 menunjukan proses pembuatan running text LED. Bahan-bahan yang digunakan dalam pembuatan running text LED adalah dot matrix p10 green $32 \times 16$ cm @ 3 pcs, microcontroller NodeMCU ESP8266, ic 74HC595, power supply unit, resistor $220 \mathrm{ohm}$, komponen pelengkap seperti frame almunium, kabel, solasi.

Setelah kode pemograman dimasukkan ke algoritma, kemudian dilakukan perakitan mekanik running text LED. Sistem ini dirancang agar penyetingan karakter dapat dikendalikan menggunakan smartphone android. Skematik wiring komponen pada NodeMCU dapat dilihat pada Gambar 4 (Taryudi dan Budi 2018). Sementara itu Gambar 5 menjelaskan cara kerja sistem (Nataprawira, Rizal, dan Wibowo 2020). Pada display dot matriks juga dapat disetting untuk bergerser dari kiri ke kanan dengan kecepatan para pembaca normal 200- 250 kpm (kata per menit), dengan waktu pengiriman teks kurang dari satu detik (Mulyati, 2009).
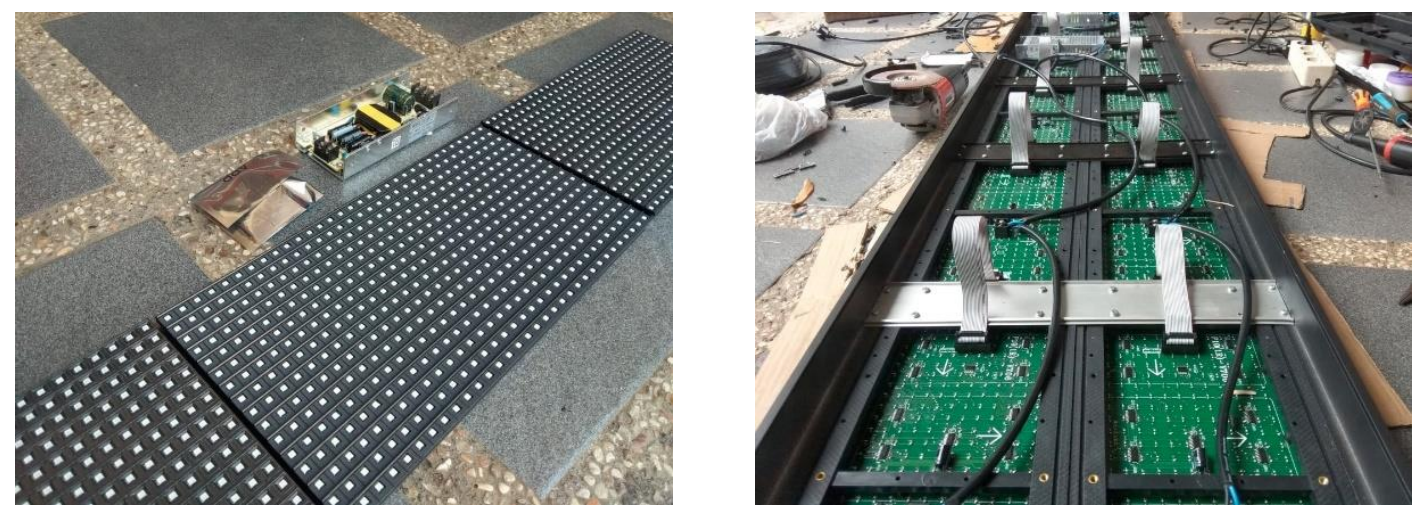

Gambar 3. Proses Pembuatan Running Text LED

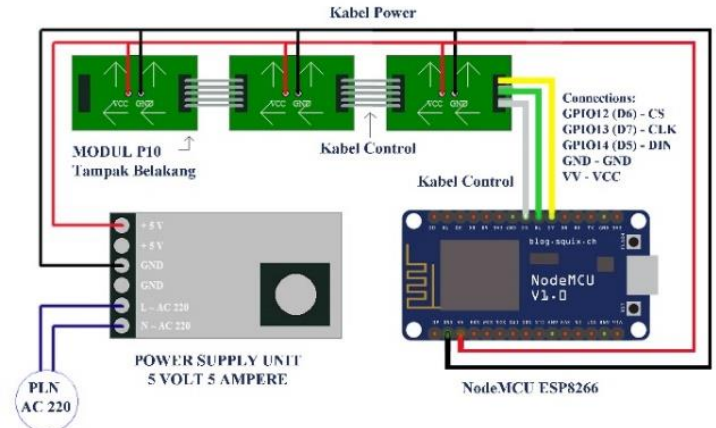

Gambar 4. Wiring Komponen Running Text LED 


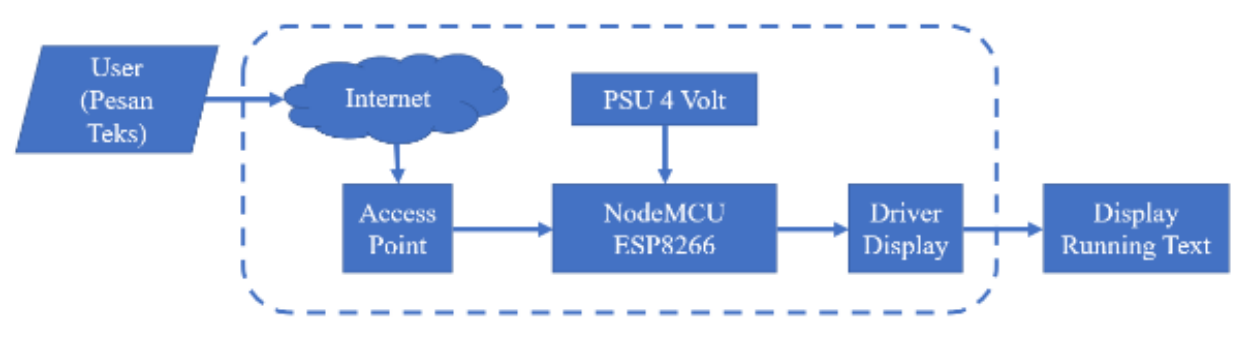

Gambar 5. Blok Diagram Sistem Running Text LED

\section{Pelatihan Mengoperasikan Running Text LED}

Tahap ketiga adalah pelatihan mengoperasikan running text LED tentang cara mensetting, mengoperasikan, dan merawat running text LED tersebut. Sebagai narasumber adalah tim dari Jurusan Teknik Mesin Politeknik Negeri Malang dan sebagai pihak peserta ialah takmir dan santri Mushola Nurul Huda seperti yang terlihat pada Gambar 6. Pelatihan diselenggarakan di aula kelas Ponpes Nurul Huda pada tanggal 16 Agustus 2020.
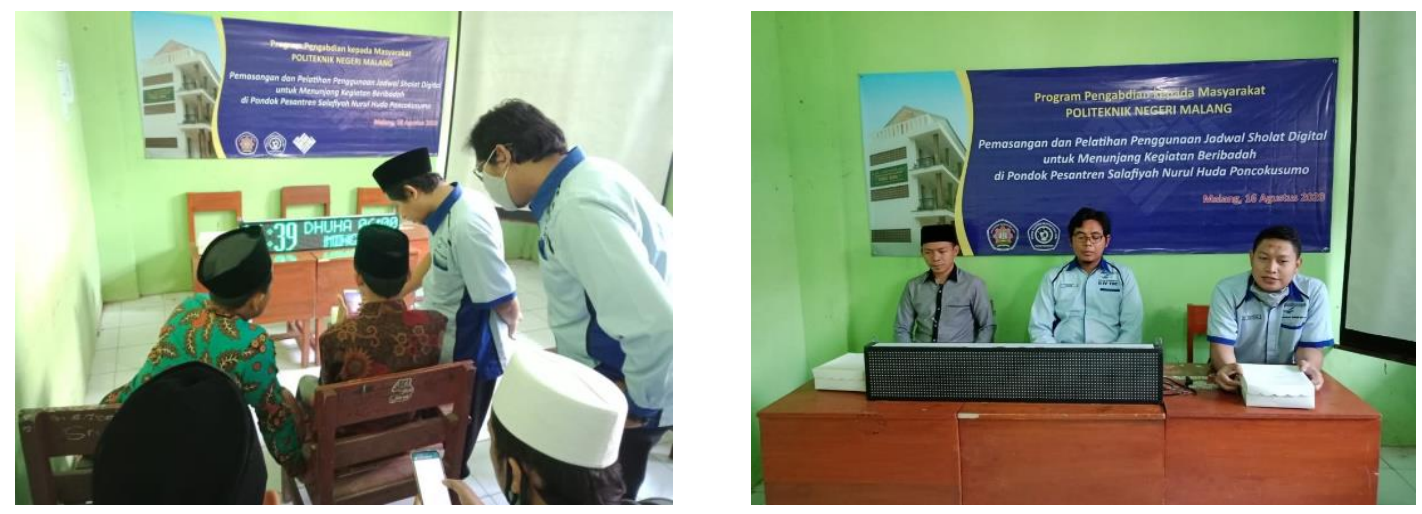

Gambar 6. Pelatihan Mengoperasikan Running Text LED

Materi pelatihan seputar pengoperasian running text LED menggunakan aplikasi Khalifah JWS WiFi versi terbaru. Dengan aplikasi running text LED dapat dikendalikan dan diatur menyesuaikan kebutuhan mushola. Terdapat beberapa fitur yang diajarkan kepada para peserta pelatihan, diantaranya adalah sebagai berikut:

a. Setting password wifi

Secara default, password dari aplikasi ini ialah 12356789 dan dapat diubah sesuai keinginan.

b. Setting fitur nama meliputi setting nama hari, nama waktu sholat, nama bulan hijriyah, dan nama bulan masehi. 
c. Setting fitur auto tartil

Terdapat beberapa opsi pilihan yang dapat dipilih yakni: play manual, auto tartil, auto azan, dan reset auto tartil.

d. Setting fitur display

Fitur ini berkaitan langsung dengan tampilan yang akan muncul pada running text LED. Beberapa hal yang bisa dilakukan pada menu ini ialah mengatur tingkat kecerahan, kecepatan teks berjalan, panel, style jam, mode malam, tampilan ketika off, dan polaritas.

e. Setting fitur teks

Pada menu ini bisa diatur teks apa saja yang akan ditampilkan pada layar running text $L E D$, diantaranya adalah pesan pembukaan, format tanggal, pesan ketika azan dan iqomah, pesan untuk meluruskan saf, pesan khusus ketika khotbah jumat, dan pesan terjadwal. Gambar 7 dan Gambar 8 menunjukkan tampilan fitur utama dan fitur setting display.

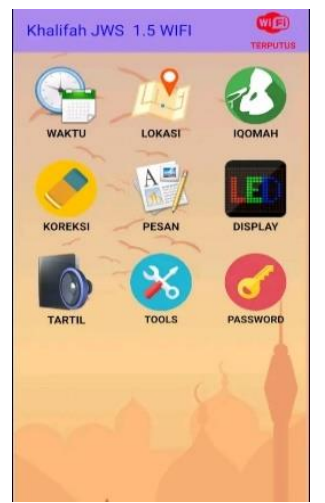

Gambar 7. Tampilan Utama Aplikasi Khalifah JWS 1.5 WiFi

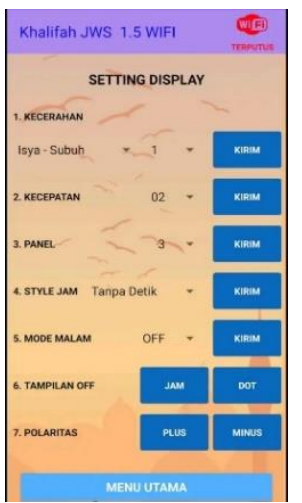

Gambar 8. Tampilan Setting Display

\section{Pemasangan Running Text LED}

Tahap terakhir adalah pemasangan running text LED di dinding atas samping Mushola Nurul Huda. Setelah pelatihan selesai maka langsung dilakukan pemasangan dan instalasi kabel untuk running text LED oleh mahasiswa polinema serta melibatkan santri dan takmir Mushola Nurul Huda Pondok Pesantren Nurul Huda. Dokumentasi pemasangan dapat dilihat pada Gambar 9 di bawah ini. 

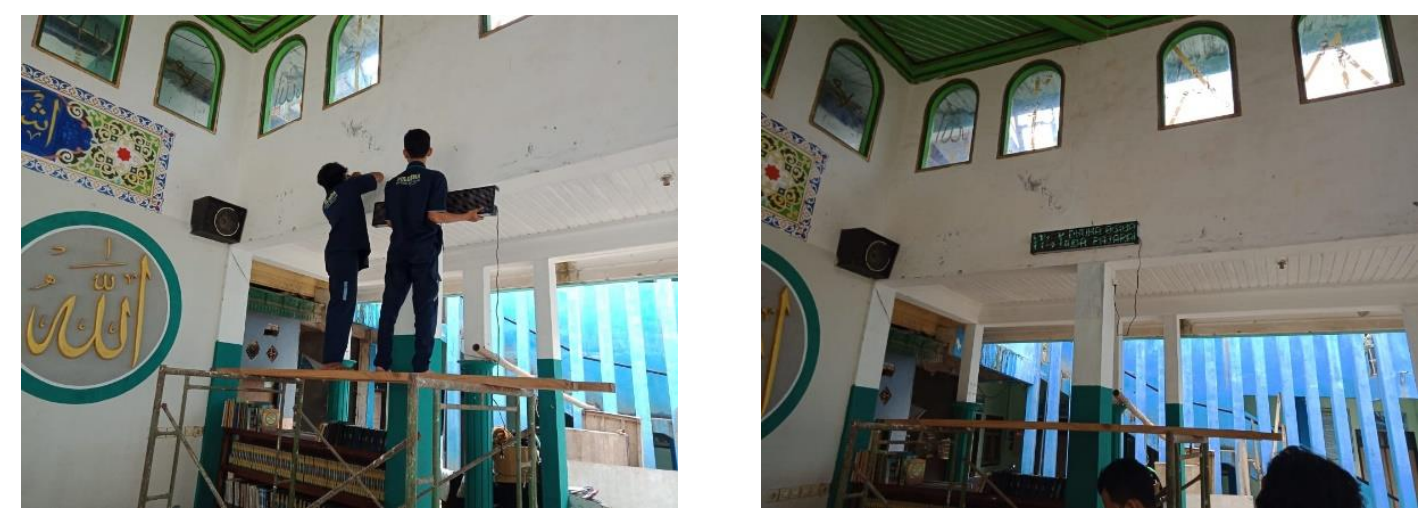

Gambar 9. Pemasangan Running Text LED

\section{Hasil dan Pembahasan}

Hasil dan pembahasan dari kegiatan ini meliputi:

\section{Pembuatan Running Text LED}

Hasil capaian dalam pembuatan running text LED adalah pertama terbelinya bahan yang sesuai kebutuhan. Kedua pembuatan frame running text LED yang pas sesuai dimensi yang direncanakan. Ketiga pemograman pada microcontroller yang berhasil dan berfungsi dengan baik. Keempat perakitan running text LED secara keseluruhan serta dilakukan uji coba dan alat berfungsi dengan baik ditunjukkan dengan semua LED SMD menyala dan program berjalan sesuai yang diinginkan. Pembuatan running text LED yang selesai tepat waktu sebelum penyerahan, pelatihan, dan pemasangan ke Mushola Nurul Huda dengan waktu pengerjaan kurang lebih satu minggu.

\section{Pelatihan Mengoperasikan Running Text LED}

Hasil capaian dari pelatihan mengoperasikan running text LED adalah pertama terselenggaranya acara pelatihan yang di hadiri oleh takmir dan beberapa santri Mushola Nurul Huda dengan total peserta 7 orang. Kedua tersampaikannya materi pelatihan dengan metode mengajari cara penggunaan aplikasi secara lisan dan mendampingi secara langsung sambil peserta mempraktikkan. Materi yang disampaikan pada pelatihan mengoperasikan display LED dot matrix atau running text LED ini terdiri dari download aplikasi Khalifah JWS 1.5 WiFi, login ke Wifi ESP8266 running text LED, pengaturan lokasi, pengaturan waktu sholat, pengaturan alarm azan dan iqomah, pengaturan pesan text berjalan, pengaturan tampilan LED, pengaturan mode silent.

Ketiga acara berlangsung dengan lancar dan semua peserta sangat antusias dengan bertanya dan diskusi terutama masalah penyetingan waktu sholat yang dimundurkan, penyetingan waktu jeda antara azan dan iqomah, dan penulisan 
pesan-pesan dalam running text LED. Keempat tercapainya kemampuan mengoperasikan running text LED hampir semua peserta sudah bisa mengoperasikan dan langsung mempraktikan untuk merubah settingan sesuai yang diinginkan. Pelatihan mengoperasikan running text LED kurang lebih dilaksanakan selama 45 menit. Kendala yang dihadapi adalah molornya pelaksanaan acara karena harus menunggu Pengasuh Pondok Pesantren Nurul Huda untuk serah terima alat.

\section{Pemasangan Running Text LED}

Hasil capaian dari pemasangan running text LED adalah pertama terinstalasi kabel steker di dekat area pemasangan berjarak satu meter dari running text LED sebagai sumber daya listrik untuk menyalakan running text LED. Kedua tertancapnya paku cor di dinding samping kanan bagian atas Mushola Nurul Huda dengan kedalaman $3 / 4$ dari panjangnya yang akan digunakan sebagai pengait running text LED. Ketiga terpasangnya running text LED secara kokoh di dinding Mushola Nurul Huda dengan ketinggian dan angle view yang pas. Pada proses pemasangan running text LED ini membutuhkan dudukan tangga yang cukup tinggi dan sedikit kendala pada proses penancapan paku yang agak lama dikarenakan struktur dinding yang keras.

Kegiatan pengabdian kepada masyarakat ini telah selesai dan berhasil dilaksanakan dengan baik. Perangkat jam digital jadwal sholat telah diserahkan kepada pengurus Mushola Nurul Huda Pajaran Kecamatan Poncokusumo, Malang. Dengan adanya running text ini diharapkan dapat bermanfaat bagi pengurus dan jamaah Mushola Nurul Huda dalam melaksanakan sholat tepat waktu dan keteraturan/kebersamaan jamaah melakukan sholat sunah antara azan dan iqomah. Gambar 12 memperlihatkan suasana serah terima running text LED secara langsung kepada pimpinan pondok pesantren dan sekaligus takmir Mushola Nurul Huda.
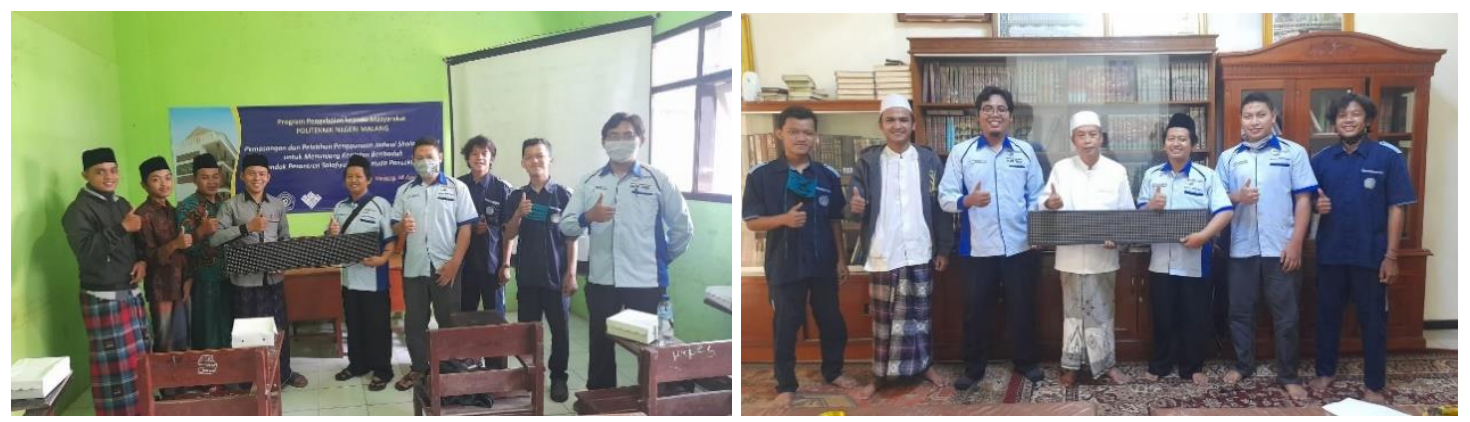

Gambar 10. Serah Terima Running Text LED kepada Pihak Ponpes Nurul Huda. 


\section{Kesimpulan}

Kesimpulan kegiatan pengabdian kepada masyarakat ini adalah:

1. Alat display LED dot matrix berbasis NodeMCU ESP8266 atau running text LED berfungsi dengan baik hal ini ditunjukkan dengan semua LED SMD menyala dan program juga berjalan dengan baik.

2. Acara pelatihan berjalan dengan lancar, dibuktikan dengan para peserta bisa memahami dan dapat mengoperasikan running text dengan baik menggunakan perangkat android dengan aplikasi Khalifah JWS 1.5 WiFi.

3. Pemasangan running text LED berjalan dengan baik, terbukti dengan langsung dipasang dengan kokoh di dinding atas bagian samping Mushola Nurul Huda dan jamaah serta santri bisa langsung merasakan manfaatnya.

\section{Ucapan Terima Kasih}

Terima kasih kepada UPT P2M Politeknik Negeri Malang sebagai penyedia dana yang bersumber dari dana DIPA Nomer: SP DIPA-023.18.2.677606/2020 Politeknik Negeri Malang dalam kegiatan pengabdian masyarakat dan Pondok Pesantren Nurul Huda, Desa Pajaran, Kecamatan Poncokusumo, Kabupaten Malang.

\section{Referensi}

Finawan, Aidi, and Yusman Yusman. 2020. "Pelatihan Instalasi Dan Konfigurasi Tampilan Papan Informasi Running Text Berbasis Jaringan WIFI Di Gampong Uteunkot Kota Lhokseumawe." In Prosiding Seminar Nasional Politeknik Negeri Lhokseumawe. Vol. 3.

Mulyati, Yeti, and A Pengantar. 2009. "Kecepatan Efektif Membaca: Apa, Mengapa, Dan Bagaimana?" Bahasa Dan Sastra Indonesia Di Tengah Arus Global. Bandung: Jurusan Pendidikan Bahasa Dan Sastra Indonesia.

Nasrullah, Emir, Agus Trisanto, and Misfa Susanto. 2019. "PELATIHAN MENGGUNAKAN JAM DIGITAL JADWAL SHOLAT UNTUK MENUNJANG KEGIATAN BERIBADAH DI MUSHOLA NURUL IMAN." In SENAPATI Seminar Nasional Pengabdian Kepada Masyarakat Teknologi Dan Inovasi. Fakultas Teknik Universitas Lampung.

Nataprawira, Alvy Suhandi, Achmad Rizal, and Agung Surya Wibowo. 2020. "Perancangan Display Led Dot Matrix Via Wi-Fi Menggunakan Aplikasi Mobile Android." INTECH 1, no. 1: 1-7.

Taryudi, Davin Bagas Adriano, and Wahyu Apsari Ciptoning Budi. 2018. "Iot-Based Integrated Home Security and Monitoring System." In IOP Conf. Series: Journal of Physics: Conf. Series, 1140:12006.

Waluyo, Catur Budi, and Sekolah Tinggi Teknologi Adisutjipto. 2018. "PELATIHAN PEMBUATAN RUNNING TEXT BERBASIS MATRIX DISPLAY LED DENGAN 
MENGGUNAKAN HD-U6A." KACANEGARA Jurnal Pengabdian Pada Masyarakat 1, no. 1: 7-12.

Wijaya, Chandra, and Pascal Alfadian. 2015. "Implementasi Jam Tersinkronisasi Dengan Menggunakan Arduino Dan Protokol RS-485." Research ReportEngineering Science 2.

Zainuri, Akhmad, Unggul Wibawa, and Eka Maulana. 2016. “Implementasi Bluetooth HC-05 Untuk Memperbarui Informasi Pada Perangkat Running Text Berbasis Android." Jurnal EECCIS 9, no. 2: 163-67.

Zondra, Elvira, and Hazra Yuvendius. 2018. "PELATIHAN PEMANFAATAN APLIKASI ARDUINO DALAM RANCANG BANGUN JAM DIGITAL." 